\title{
Preserving Performing Arts through Homestay Programme: Lesson learnt from Bidayuh Annah Rais Longhouse Tourism's experience
}

\author{
Samat, Tracy Peter \\ Faculty of Social Sciences, Universiti Malaysia Sarawak, \\ Kota Samarahan, Malaysia
}

Samani, Mus Chairil

Faculty of Language and Communication Studies, Universiti Malaysia Sarawak,

Kota Samarahan, Malaysia

Marwan, Nurul Huda

Faculty of Social Sciences, Universiti Malaysia Sarawak,

Kota Samarahan, Malaysia

Maliki, Jamilah

Faculty of Language and Communication Studies, Universiti Malaysia Sarawak, Kota Samarahan, Malaysia

*Corresponding author

Email address: pstracy@unimas.my

\begin{abstract}
The Bidayuh people are one of the indigenous communities who often get the highlight from tourists during their stay in Kuching, the capital city of Sarawak. Their performing arts notably, the dance and music are often commercialized and staged to tourists, who would visit the prominent Bidayuh longhouse in Annah Rais village, located at the Padawan District. This paper is based on empirical studies that explores and identifies the significance of homestay programme as one of the rural community-based tourism developments and the role of homestay proprietors to perpetuate and preserve the Bidayuh performing arts. The research findings are based on in-depth interview with the homestay proprietors as well local and foreign visitors and tourists during their visit or stay in the village. The twofold findings reveal that the interplay between homestay programme and proprietors are crucial in shaping tourist's meaningful experiences which ultimately imperative in the planning and management of rural community-based tourism for sustainable development.
\end{abstract}

Keywords: performing arts, community-based tourism, homestay, cultural heritage, Bidayuh 


\section{INTRODUCTION}

According to Russell (2000), the emerging trends in Community based tourism (CBT) studies projected on two focal points; consumer and, political pressure for sustainable development. This reflected in the objectives of the CBT development which emphasize on three goals; advocacy of local participation in the development, economic benefits gain by the people living around the destination and thirdly, to protect the cultural identity and natural environment. Globally, CBT framework is commonly adopted by countries to develop the potential rural destination for tourism development. Potential in this context is measured by the socioeconomic, cultural and environmental benefits to name a few such as, employment opportunity, source of income, enhancement of infrastructures development, development of small enterprises, local involvement in management and planning, preservation of cultural heritage and natural environment.

The development of CBT is also equated with the agenda to eradicate rural poverty by creating web of employment opportunities. Often than not, rural poverty is associated with characteristics such as minority group, indigenous or aboriginal ethnic group of the country. Although these characteristics are not generally acceptable to conceptualize rural poverty yet, the root of CBT development in rural settings often resembles these characteristics. This is due to the common perceptions about the group as culturally unique and attractive and therefore it is utilised as a 'winning point' to promote CBT development. Researches conducted by Goodwin (2007) and his coauthored paper (cf. Ashley, C., et al. 2000) support the claim that the tourism agenda in indigenous setting is mainly to reduce poverty.

In Southeast Asia, CBT development is also majorly targeting rural setting that matches either one or more of the following characteristics: minority, indigenous or aboriginal, poor and perceived as culturally unique. Although these characteristics are often overstate in labeling the rural community yet, often the rural community that engages in CBT confined to these label. This conformity can be described as a 'win-win situation' in CBT development which embedded in the concept of 'cost and benefits'. Research conducted by Harrison and Schipani (2007) in Lao People's Democratic Republic exemplified the 'win-win situation' whereby the local pro-poor community negotiate their identity in a return for socioeconomic benefits.

In Malaysia, the framework of CBT development operates by incorporating the homestay programme. The programme becomes an iconic rural CBT development since 1988, an initiative promoted by The Ministry of Tourism (Pusiran \& Xiao 2013). The package of CBT development then diversified which include cultural attractions such as local performing arts (dance, music), delicacies, history, engage in local daily activities, village tour and visit to natural attraction (waterfall, hot spring, jungle trekking, river). The diversification of attractions is to sustain the CBT development which is an important catalyst for rural community socioeconomic development. As for the local community this programme also perceives as vital since it contributes in perpetuating their cultural heritage particularly the arts performances. The showcase of arts in CBT development is believed to be the key holder in constructing tourist's meaningful travel experiences.

As one of the states in the eastern part of Malaysia, CBT development in Sarawak does not only targeting the poor rural community but also reaching out to the rural community that represents the element of its culturally 'unique' and 'authentic' aspect. In describing these two terms, longhouse communities reflect the characteristics. Authors such as Kedit (1980), Kedit and Sabang (1993), Zepple (1995; 1997), Dias (2001) and Sanggin (2009) demonstrate that longhouse community particularly the Iban is the major catalyst in the longhouse tourism development in Sarawak. This followed by other longhouses such as the Bidayuh in Annah Rais, Benuk and Mongkos villages, the Kayan Uma Belor Sg. Asap Belaga, the Kelabit Bario highlands and the Lunbawang Ba'kelalan, Lawas which are highlighted in Sarawak Homestay Directory (n.d.) as attractive places in the state. Each of these longhouses offers diverse fascinations ranging from cultural to village scenery or environmental attraction. 
This research however focuses on the Bidayuh Annah Rais longhouse village (BARL) to hear and learn from the homestay's proprietors and tourists experiences on their involvement in the homestay activities particularly in relations to the performing arts (dance and music). Thus, the primary objective of this paper is to examine the interplay between performing arts, tourism and experiences in the BARL. The critical analysis on the interplay between arts, entertainment and tourism has been written extensively by Hughes (2000) which worth of repeating and address for comparison. Additionally, to expand Hughes's (2000) work, there are two major elements scrutinize in this paper: the role of homestay proprietors as it play major role in promoting tourism and fulfill tourists' needs as well in preserving cultural heritage; and, performing arts as 'active cultivation of the human mind' (Williams, 1981) to examine the significant of arts in contextualize tourist's experiences. Tourism's impact on the arts (Hughes, 2000) and, Quality Tourism Experiences (Jennings \& Nickerson, 2006) frameworks are adopted in this paper to measure the significant of homestay programme in preserving Bidayuh performing arts as well to assess tourist's experiences.

The data collected for this research are based on self-administrated survey and follow up by in-depth interviews with the homestay proprietors and tourists. There are fourteen homestays in the village approached for this research and seven homestay's proprietors had expressed their willingness to participate in this research. These homestays are namely: Edward homestay, Macheree homestay, Joda homestay, Jenny homestay, Valerie homestay, Esah homestay and Emily homestay. Meanwhile there are 150 tourists whom were either staying overnight or on a daytrip visit were interviewed for this research. The purpose of conducting in-depth interviews is to gather on the information about the who, what, when, why and how homestay proprietors operate their homestay programme. Specifically, in-depth interviews are used to obtain information about the homestay package and tourist's perception about the package offered particularly on the performing arts. This technique allows researchers to identify tourist's needs that try to be fulfilled by the homestay proprietors. The in-depth interview data are analysed according to categorization approach meanwhile the selfadministrated survey data are input into the SPSS software. However, in accordance to the objectives of this research paper, only few data were selected and reported.

\section{THE ARTS CONCEPT}

It is important to note that there are distinctions between the terms 'arts' and 'entertainment'. The detailed characteristics of both terms are framed by Hughes $(2000 ; 13)$ in the following table. As shown in the table, the characteristics of 'arts' can be interpreted as more meaningful and relevant to coin in this research paper although Hughes $(2000 ; 13)$ highlight that the characteristics of 'arts' are majorly referring to 'high arts' such as classical music, ballet, plays, opera as well as paintings and sculpture. Nonetheless, the rational of using the term 'arts' in this paper is to highlight that the application of arts concept is subjective and contextualizes and not necessarily referring to 'high arts' as propose by Hughes (2000). Moreover, to assess the role of performing arts in 'cultivate active human mind', the characteristics of arts serve the purpose. According to Williams (1981) the cultivation of active human mind depends on meaningful experiences (which reflected in the characteristic of arts) that shape individual interpretation. Hence, rather than use the term entertainment in describing the performing arts (dance and music) in BARL, the term 'arts' is coined in this paper (Table 1).

TABLE 1: Some terms used in relation to the arts and entertainment 


\begin{tabular}{|c|c|}
\hline refinement & enjoyment \\
learned & frivolous \\
serious & passive \\
creative & self-indulgent \\
enlightment & pleasure \\
expressive & fun \\
fundamental & excitement \\
purposeful & escapist \\
emotional & delight \\
inspirational & amusement \\
culture & transitory \\
& \\
\hline
\end{tabular}

Source: Hughes, 2000:13

\section{COMMUNITY-BASED TOURISM DEVELOPMENT}

Globally, tourism industry is one of the important agents in contributing socioeconomic development of a country (cf. Hughes 2000). However, in Southeast region, Malaysia is relatively new in the promotion of tourism which kick starts in 1987 (Sanggin, 2009: 15). In Sarawak, the diversity of ethnic groups and the uniqueness of their cultures served as a complete package to promote tourism development particularly rural CBT development. According to Murphy (1985 cited in Othman et al. 2013), CBT concept is introduce in rural development as it seen more compatible in rural context. Othman et al. (2013) describe CBT as tourism development that emphasis on bottom-up approach. An approach that encourage "local input, and control over the type, scale, and intensity of tourism development" (Othman et al 2013: 66). However, important to note that in the case of the Bidayuh Annah Rais longhouse (BARL), the CBT development is not solely controlled by the local. In fact, it integrates with a various tourism networks such as The Ministry of Tourism and Culture, Ministry of Tourism Sarawak, Sarawak Tourism Board, homestay proprietors, travel agencies, tourist, and worldwide web (Samat, 2011). Hence, it is significant to revisit and assess the CBT concept periodically to determine the relevant-ness of the contextual application. Moreover, the success and failure story of CBT development also determine by the various tourism networks.

\section{HOMESTAY PROGRAMME}

Research on homestay programme in Malaysia and its general contribution in tourism development are flourished by interdisciplinary researchers. The School of Economic and Business, Tourism and Hospitality Management and, School of Tourism Hospitality and Environmental Management tend to analyses homestay programme within the economic and hospitality matrices such as cost and benefits whereas the School of Education, Arts and Social Sciences incline to integrate the elements of arts and humanities in their research such as issues, challenges and local perceptions of the programme. Nowadays, the trend is shifting; most of the researches on homestay programme in Malaysia regardless of Schools and expertise integrates transdisciplinary approach in their research. Some of the examples are research paper written by Sita \& Mohd Nor (2015) published in Journal of Management Research entitled Local Perceptions towards Tourism Impacts Related to Homestay Programme, with a focus on tourist and local communication; Pusiran \& Honggen (2013) who are both affiliated with School of Hotel and Tourism Management, Hong Kong Polytechnic University, wrote a research paper on Challenges and Community Development: A case study of Homestay in Malaysia, focus on community development through the homestay programme; and Vinh's (2013) research paper entitle Destination Culture and Its Influence on Tourist Motivation and Tourist Satisfaction of Homestay that employ marketing and business approach in the paper. These research trends demonstrate a burgeoning multidisciplinary approach in studying the issues in relations to homestay programme. This paper however integrates the social sciences dimension, emphasize on the 
anthropological context to provide deeper understanding in analysing homestay programme in BARL. As such, the methodological components and epistemological contexts such as tourists and host interactions and experiences and, cultural heritage are address as important objectives of this paper which incorporate two important data collection methods, self-administrated survey and in-depth interview.

The historical development of homestay programme was documented by Razzaq et al. (2011). According to the authors, the homestay programme can be traced back in the early 1970s by the early visit of 'drifter enclave' of Kampung Cherating Lama in Pahang. The hospitality offer to the early drifter was just basic needs such as breakfast, dinner and space to sleep in humble kampung. These basic needs still resembles in today's homestay programme in Malaysia with additional cultural performances, environment sightseeing and direct and indirect involvement of tourist in local daily activities during their stay or visit. The later component of the homestay programme according to Razzaq et al. (2011) serve as a unique trademark of rural homestay programme in Malaysia. This programme also enables the rural community to share their cultural uniqueness and interacts with tourists of various cultural backgrounds. In the context of BARL tourism, homestay programme encompasses of all the elements mentioned above. However, despite completely confine to Hon's (1989) perception on 'longhouse as the most saleable item to promote' and 'living under one roof experience', multi-faceted scenario can be seen in the development of BARL tourism. Those two elements are now further negotiated by both homestay proprietor (in the case of Joda's homestay in BARL in which the homestay is not situated at the longhouse) and tourists' affordability.

\section{LONGHOUSE TOURISM AND HOMESTAY PROGRAMME IN SARAWAK}

Longhouse is well-known as "a village under one roof, with family apartments joined together and a long communal gallery" (Zeppel 1995). This house structure is renowned among the Borneo indigenous dwellers and often employ as marketing strategy by the respective state, travel agencies and local in promoting tourism development in the island. In Sarawak, longhouse is often associated with the Iban, Bidayuh and Orang Ulu ethnic groups although some might have diminished the structure and opts for single dwelling or renovate the longhouses to modern structure. Hon (1989) observes the popularity of longhouse tourism in Sarawak starts with visits by international tourists to Iban longhouse. Zeppel (1997) stated Iban longhouses particularly, at the lower reach of Skrang, Lemanak, Ulu Ai and Engkiri rivers were the earliest to receive international tourists which subsequently until today adopt by the Ministry of Tourism Sarawak to promote homestay programme in the longhouse villages.

The popularization of longhouse tourism started when The Moon Handbook stated that "Sarawak's classic adventure is visiting several Iban or Bidayuh longhouses, which are scattered upriver in the ulu (rural vicinity)" (Parkes 1998: 525 cited in Dias 2001: 9). This classic adventure is also listed in the Kuching Guide, as the most important activity to perform when tourists visit Sarawak particularly the Iban longhouse (Tarman \& Reed 1999: 63 cited in Dias 2001: 9). This perception is, however, contradicted by the 'Marketing and Promotion Director for the Sarawak Tourism Board, Jean-Christophe Robles-Espinoza who predicted that eco-tourism will be more important than longhouse tourism in the state (Iskandar 2000: 17 cited in Dias 2001: 9). This is because some analysts such as Hon observed that the 'quality of the experience in a few longhouses is slow depreciating' (1989: 287). Hence, in the case of BARL tourism, the homestay programme and eco-tourism are packaged as one to attract the arrival of tourists. Overall, the longhouse programmes in Sarawak are also diversified to ensure the sustainability of the CBT development (Table 2). 
TABLE 2: Activities for longhouse homestay programme in Sarawak

\begin{tabular}{|c|c|c|c|c|}
\hline \multirow{2}{*}{$\begin{array}{l}\text { Longhouse } \\
\text { Homestays }\end{array}$} & \multirow{2}{*}{$\begin{array}{l}\text { Ethnic } \\
\text { Group }\end{array}$} & \multicolumn{3}{|c|}{ Attractions } \\
\hline & & Culture and way of life & Eco-activities & $\begin{array}{l}\text { Economic } \\
\text { activities }\end{array}$ \\
\hline $\begin{array}{l}\text { Annah Rais } \\
\text { Homestay, } \\
\text { Kuching }{ }^{1}\end{array}$ & \multirow[t]{3}{*}{ Bidayuh } & $\begin{array}{l}\text { Longhouse architecture \& } \\
\text { lifestyles: } \\
\text { Pangah (Head skulls' } \\
\text { house) } \\
\text { Traditional longhouse } \\
\text { show-house } \\
\text { Bamboo bridge walk } \\
\text { Hunting with the } \\
\text { blowgun show } \\
\text { Cooking bamboo rice } \\
\text { and bamboo chicken } \\
\text { (pansuh) } \\
\text { Basket weaving } \\
\text { *Private mini museum } \\
\text { (erected by Edward } \\
\text { homestay) } \\
\text { History, Dance, songs, music, } \\
\text { traditional costume, } \\
\text { Traditional cuisine (pansuh, } \\
\text { bamboo rice, jungle } \\
\text { vegetables (midin and fern), } \\
\text { tuak (local rice wine) } \\
\text { Local handicraft } \\
\text { Harvest Festival (1st \& 2nd } \\
\text { June yearly) }\end{array}$ & $\begin{array}{l}\text { Village sightseeing } \\
\text { Jungle tracking \& } \\
\text { BBQ lunch at the } \\
\text { river or waterfall } \\
\text { Bamboo rafting } \\
\text { Waterfall } \\
\text { Hot-spring } \\
\text { Visit nearest } \\
\text { attraction - Orang } \\
\text { Utan Rehabilitation } \\
\text { Centre, wild orchids } \\
\text { \& Rafflesia }\end{array}$ & $\begin{array}{l}\text { Paddy } \\
\text { harvesting } \\
\text { (February } \\
\text { April) } \\
\text { Fishing }\end{array}$ \\
\hline $\begin{array}{l}\text { Kampung } \\
\text { Benuk } \\
\text { Homestay, } \\
\text { Kuching }^{2}\end{array}$ & & $\begin{array}{l}\text { Longhouse architecture \& } \\
\text { lifestyles } \\
\quad \text { Mini museum (Kpg. } \\
\quad \text { Benuk) } \\
\text { Baruk } \\
\quad \text { Bamboo bridge walk } \\
\text { History } \\
\text { Dance, songs, music, } \\
\text { traditional costume, } \\
\text { traditional cuisine } \\
\text { Local handicraft } \\
\text { Harvest Festival (1st \& } 2 \text { nd } \\
\text { June yearly) }\end{array}$ & $\begin{array}{l}\text { Village sightseeing } \\
\text { Legendary site } \\
\text { Bamboo rafting } \\
\text { Mountain climbing } \\
\text { Visit nearest } \\
\text { attraction - Orang } \\
\text { Utan Rehabilitation } \\
\text { Centre, wild orchids } \\
\text { \& Rafflesia }\end{array}$ & $\begin{array}{l}\text { Paddy } \\
\text { harvesting } \\
\text { (April or May) }\end{array}$ \\
\hline $\begin{array}{l}\text { Mongkos } \\
\text { Homestay, } \\
\text { Kuching }^{3}\end{array}$ & & $\begin{array}{l}\text { Longhouse architecture \& } \\
\text { lifestyles } \\
\text { Harvest Festival (1st \& } 2 \text { 2nd } \\
\text { June yearly) }\end{array}$ & $\begin{array}{l}\text { Waterfall } \\
\text { Flora and fauna } \\
\text { Trekking and } \\
\text { adventure caving }\end{array}$ & $\begin{array}{l}\text { Pepper garden } \\
\text { \& tropical fruits } \\
\text { (during fruit } \\
\text { season) }\end{array}$ \\
\hline
\end{tabular}

\footnotetext{
${ }^{1}$ Information obtained from Sarawak Homestay Directory; Research fieldwork (RAGS) for Uses and Gratification perspective on Ethnic Tourism at Kampung Annah Rais.

${ }^{2}$ Information obtained from Sarawak Homestay Directory.

${ }^{3}$ Information obtained from Sarawak Homestay Directory.
} 


\begin{tabular}{|c|c|c|c|c|}
\hline $\begin{array}{l}\text { Rumah Nyuka } \\
\text { Homestay } \\
\text { Sarikei }^{4}\end{array}$ & \multirow{6}{*}{ Iban } & $\begin{array}{l}\text { Longhouse architecture \& } \\
\text { lifestyles } \\
\text { Making rice wine } \\
\text { Cooking traditional food in } \\
\text { bamboo (pansuh) } \\
\text { Handicraft making }\end{array}$ & $\begin{array}{l}\text { Sungai Pau \& \& } \\
\text { Sungai Munsoh } \\
\text { Waterfalls } \\
\text { Jungle trekking }\end{array}$ & $\begin{array}{l}\text { Rubber tapping } \\
\& \text { processing } \\
\text { the rubber }\end{array}$ \\
\hline $\begin{array}{l}\text { Bawang Assan } \\
\text { Homestay } \\
\text { Sibu }^{5}\end{array}$ & & $\begin{array}{l}\text { Longhouse architecture \& } \\
\text { lifestyles } \\
\text { Unique Iban culture } \\
\text { Playing traditional musical } \\
\text { instrument } \\
\text { Ngajat dance performance } \\
\text { Weaving pua kumbu textile }\end{array}$ & $\begin{array}{lr}\text { Long boat } & \text { river } \\
\text { safari } & \\
\text { Riverine } & \text { sports } \\
\text { fishing } & \end{array}$ & \\
\hline $\begin{array}{l}\text { Rumah } \\
\text { Benjamin } \\
\text { Angki } \\
\text { Homestay } \\
\text { Sibu }^{6}\end{array}$ & & $\begin{array}{l}\text { Longhouse architecture \& } \\
\text { lifestyles } \\
\text { Making tikar bemban (mat) } \\
\text { Blowpipe demonstration }\end{array}$ & $\begin{array}{l}\text { Fishing safari } \\
\text { Tut-tut boat tour }\end{array}$ & \\
\hline $\begin{array}{l}\text { Rumah Hillary } \\
\text { Tawan Achai } \\
\text { Homestay } \\
\text { Marudi, Miri }{ }^{7}\end{array}$ & & $\begin{array}{l}\text { Modern longhouse } \\
\text { architecture } \\
\text { Longhouse lifestyles }\end{array}$ & Jungle trekking & $\begin{array}{l}\text { Paddy planting/ } \\
\text { harvesting } \\
\text { Fishing }\end{array}$ \\
\hline $\begin{array}{l}\text { Rumah Patrick } \\
\text { Homestay } \\
\text { Miri }^{8}\end{array}$ & & $\begin{array}{l}\text { Longhouse architecture \& } \\
\text { lifestyles } \\
\text { Cultural activities }\end{array}$ & $\begin{array}{lr}\text { Visiting nearest } \\
\text { attractions: Niah } \\
\text { cave (historical site), } \\
\text { Birds nest in the } \\
\text { Niah Cave, } \\
\text { Adventure caving, } \\
\text { flora and fauna } \\
\text { sightseeing }\end{array}$ & \\
\hline \begin{tabular}{l}
\multicolumn{2}{l}{ Rumah Wilson } \\
Bana Kpg Po \\
Ai Melugu \\
Homestay Sri \\
Aman
\end{tabular} & & $\begin{array}{l}\text { Longhouse architecture } \\
\text { (sadau, pantar, ruai \& } \\
\text { tempuan) \& lifestyles } \\
\text { Grinding rice } \\
\text { Ngajat dance } \\
\text { Cooking rice \& chicken in } \\
\text { bamboo (pansuh) } \\
\text { demonstration } \\
\text { Weave "pua kumbu" textile }\end{array}$ & & \\
\hline $\begin{array}{l}\text { Sungai Asap } \\
\text { Homestay } \\
\text { Belaga }^{10}\end{array}$ & Kenyah & $\begin{array}{l}\text { Longhouse architecture \& } \\
\text { lifestyles } \\
\text { Cultural performance - } \\
\text { dance, music and many more } \\
\end{array}$ & \begin{tabular}{lr}
\multicolumn{2}{l}{ Jungle trekking } \\
Visit & nearest \\
attractions: & mini \\
museum & Sungai \\
\end{tabular} & \\
\hline
\end{tabular}

\footnotetext{
${ }^{4}$ Information obtained from Sarawak Homestay Directory.

${ }^{5}$ Information obtained from Sarawak Homestay Directory.

${ }^{6}$ Information obtained from Sarawak Homestay Directory.

${ }^{7}$ Information obtained from Sarawak Homestay Directory.

${ }^{8}$ Information obtained from Sarawak Homestay Directory.

${ }^{9}$ Information obtained from Sarawak Homestay Directory.

${ }^{10}$ Information obtained from Sarawak Homestay Directory.
} 


\begin{tabular}{|l|l|l|l|}
\hline & Handicraft making & Asap, Bakun lake & \\
\hline
\end{tabular}

\section{THE BIDAYUH OF ANNAH RAIS LONGHOUSE AND TOURISM DEVELOPMENT}

The Bidayuh is one of the ethnic groups of Sarawak, predominantly found in Kuching and Samarahan divisions of Sarawak. Within these divisions, they are largely concentrated in Serian, Bau and Lundu districts and also in the Padawan and Siburan sub-districts. Linguistically, there are four main Bidayuh dialects namely; Bukar or Sadong, Biatah, Jagoi or Singai and Selakau or Lara (Chang 2002, p. 25). Annah Rais longhouse village is one of the Bidayuh villages situated in the Padawan district and is located about 65 kilometres from the city of Kuching, the state capital of Sarawak. The village established in 1834 and situated on both banks of the Simadang River (Samat, 2011). The settlement in the village is in the form of a cluster and there are two types of houses in the village-the longhouse with 64 bilik $^{11}$ and about 85 individual houses scattered along the banks of the river as well on the higher ground of the settlement. The longhouse is as old as eight generations and is divided into three sections locally known as Kupo Sebak, Kupo Terakan and Kupo Sijok.

Annah Rais village started to engage in tourism industry in the 1990 while the home-stay industry started to operate in the 2006 (Samat, 2001). As-to-date, there are fourteen homestays in the village: Edward homestay, Esah homestay, Emily homestay, Emily Mackeleen homestay, Joseph Reis homestay, Winnie homestay - which are still very active due to their own marketing strategy such as the creation of homestay webpage, promotional event via social networking (Facebook, Instagram and Twitter) and review in the Trip Advisor whereas, four homestays: Siti Mayot homestay, Areu homestay, Karin homestay and Robert Muning homestay are inactive. Thirteen homestays are registered while one homestay considered as operating 'enterprise businesses due to licensed issue. However, often than not this homestay is referred by Sarawak Tourism Board (STB) as a corresponding homestay in the village due to tourists' overwhelming feedback and comments on the homestay service. Tourists' comments are available in the homestay's respective website or social networking which are vital to assess and incorporated in the management and planning of CBT development.

\section{TOURISM EXPERIENCE AND CULTURAL HERITAGE}

Rather than assessing the tourism experiences from both affirmative and undesirable aspects, most literature highlight the positive elements of tourism experiences instead. A positive tourism experience in literature edited by Jennings \& Nickerson (2006) is term as Quality Tourism Experiences (QTE). The context of QTE are categorize thematically according to who address the matter and in what context. Re-emphasize work by Jennings \& Nickerson (2006: 6), QTE in public sources were associated with one of the following: tourist and community perspectives on host-guest interaction, tourism industry and government sector perspectives on classification of the type of tourism product, tourist perspectives on market differentiation and development and integrated or network tourism system and economic gain. These scopes are to address five important components: positive social impacts, economic benefits, environmental protection, government policy formulation and discrimination between tourism products and sustainability issues.

Meanwhile in academic literatures the focus is varied such as the importance of quality tourism products (QTP) for QTE; QTE and satisfaction; QTE and the management of tourist experiences and associated environmental issues; consequences of QTE; QTE and reputation; sustainability and QTE; QTE and host-guest interactions; quality of life; quality and profitability; modes of experience; place and identity; and QTE and motivation. Evaluate the scopes address in public access and academic literatures it can be concluded that the scopes in academic literatures are

\footnotetext{
${ }^{11}$ Generally defined as apartment
} 
more holistic, covering both 'tourism products' and 'tourism experiences'. However, the term 'Quality' should be re-assessed since it implies 'a degree of excellence' which aside the 'reverse' meaning and obsolete the core approach in sustainable development. Hence, the later discourse which is not mentioned in Jennings \& Nickerson (2006) is highlighted in this research to provide holistic assessment of tourism experiences and its important in the management of cultural heritage particularly, the performing arts. Cultural heritage is addressed as one of the goals in CBT but was not articulate comprehensively by Jennings \& Nickerson (2006) in both sources.

\section{RESULTS AND DISCUSSION}

\section{(i) The role of homestay proprietors in perpetuate Bidayuh cultural heritage}

The role of the homestay proprietors (Figure 1) in perpetuates Bidayuh cultural heritage is assessed by measuring their feedback on the music and dance performances. One of the in-depth interview questions addresses:

Do you think that the homestay operators play important role in promoting Bidayuh dance and music?

Homestay 1; 69 tourists: "Cultural dance and music are important to attract tourist to visit and revisit the village. It is part of the package for overnight tourist. For daily visitor, depends on the arrangement made by the travel agent and, homestay operators should keep up their promise as stated in their homestay website." 12

Homestay 2; 28 tourists: "Cultural dance and music are important to showcase to promote Bidayuh culture and good selling point for tourists to recommend to their family and friends. Both tourist and visitors that contacted the homestay earlier to arrange their visit will be entertained with cultural performances not just cultural dance and music but also including blowpipe demonstration."

Homestay 3; 11 tourists: "Although cultural dance and music are important in homestay programme yet, our homestay did not showcase it because tourists can always enjoy and watch the cultural performances in Sarawak Cultural Village. Our homestay emphasize more on nature and environmental activities such as jungle trekking or kampung-style picnic. But if tourist requests to have the cultural performances, we still carried it out."

Homestay 4; 10 tourists: "Oh it's very important. Both dance and music are important cultural attraction in the homestay programme and highlighted in our website". So, if we did not offer the cultural performance, the fees for the homestay package should be reduced."

Homestay 5; 20 tourists: "Yes, we do offer the cultural performance such as dance and music as part of the homestay programme and it's very important."

Homestay 6; 5 tourists: "Yes, important. But we also can't force the tourists to purchase the complete package if they can't afford or have no interest."

Homestay 7; 5 tourists: "Yes, important to promote the Bidayuh culture to tourists."

FIGURE 1: Homestay proprietors involve in the research

\footnotetext{
12 The in-depth interviews with seven homestay proprietors were conducted in Bidayuh language. Hence, the error in English translation is done purposely to retain the originality of the feedback.
} 


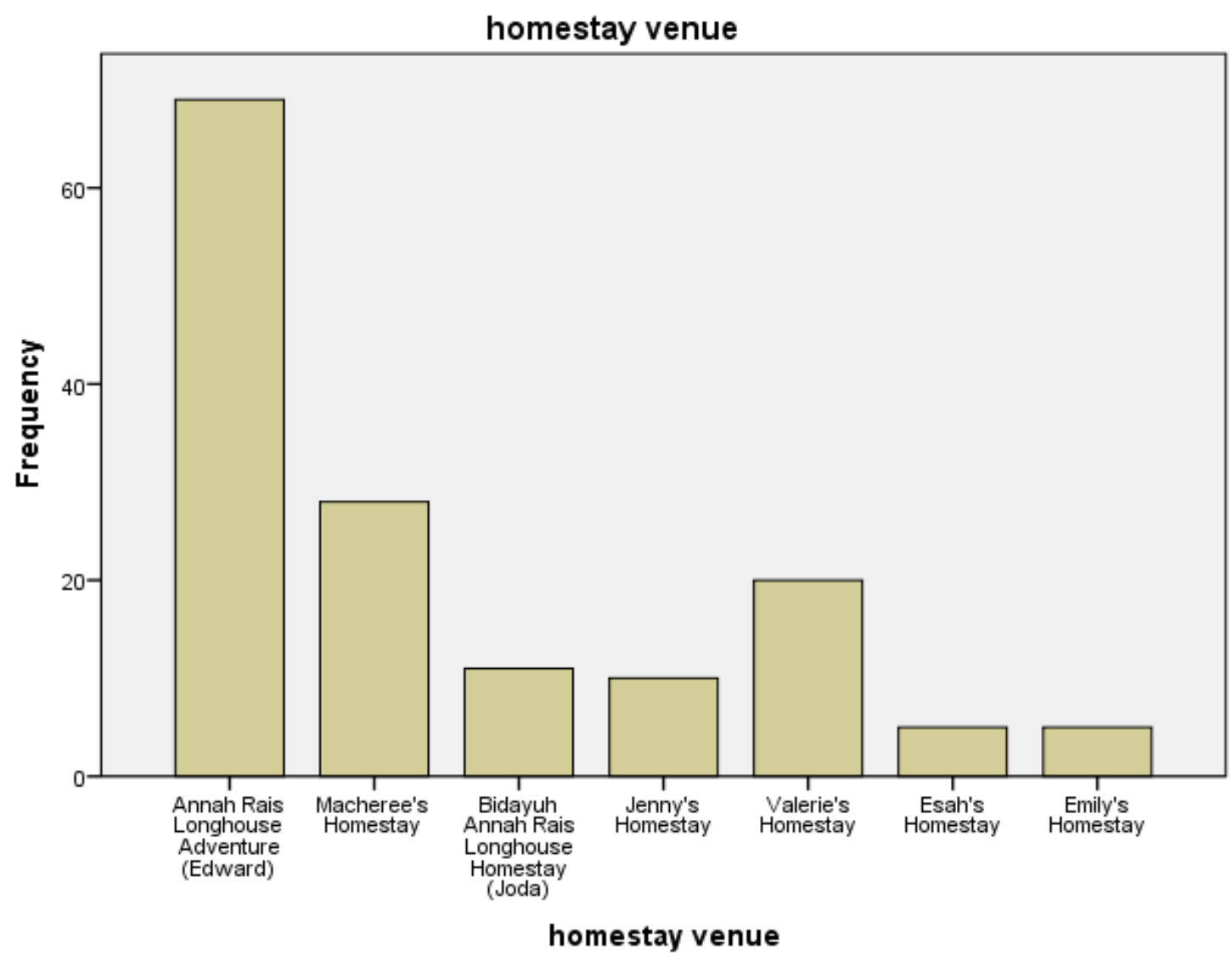

The above data shows that the role of homestay proprietors is important in perpetuating the Bidayuh cultural heritage notably the dance and music. The homestay proprietors are considered as the guardian of local cultural heritage. Nonetheless, the role in promoting the arts does not solely rely on the homestay proprietors. In fact it is also determined by few factors such as the arrangement made between the travel agency and the homestay in the case of homestay no. 1 (Edward homestay) and homestay no. 2 (Macheree homestay); tourist expanses, a feedback given by homestay no. 4 (Jenny homestay) and homestay no. 6 (Esah homestay); the homestay's proprietor emphasis on the homestay product that can be seen in the feedback given by homestay no.3 (Joda homestay) and lastly, the tourist's cultural interest in the case of homestay no. 4 (Jenny homestay) and homestay no. 6 ( Esah homestay) - these multidimensional factors lead us to relook and revise the 'tourism experiences' framework in analyzing quality and meaningful tourism's experiences, a framework highlighted by Jennings and Nickerson (2006). As exemplified by this research, a host and tourist aspect does influence the organization and structure of the homestay programme particularly in relations to the arts performance on the basis of 'negotiation and mutual understanding'. Therefore, there is a need to relook at the QTE framework since those factors does influence 'a real interpretation' of the framework. Additionally, this insight is also useful to be incorporated in cultural heritage management and planning based on the output given by host and tourists on the cultural products.

Re-addressing the main objective of this paper, it can be concluded that there is direct interplay between tourism, heritage and experiences. Tourism development via homestay programme plays crucial role in preserving local cultural heritage since only through cultural showcase that the cultural elements can be revived. However, the preservation of cultural heritage is also determined by the power of 'experiences'. Homestay proprietor's experience in dealing with tourist's demand on the cultural product as well tourist's desired experience does influence the preservation of cultural heritage, as in the case of BARL. 


\section{(ii) Tourist experiences and its importance}

Tourist's experiences were measured by 'travel experience model' by Killion (1992 cited in Jennings and Nickerson, 2006: 9) Killion's (1992) model emphasized on experiences on-site, return travel, recollection, planning and travel to. Killion's model is further refurbished by Craig-Smith and French (1994 cited in Jennings \& Nickerson, 2006: 9) emphasize on three phase of vacation experiences: anticipatory, experiential and reflective. Both constructive and unpleasant experiences were captured in the analysis which is useful for recommendation and suggestion for improvement. Additionally, only performing arts are referred to in examine Killion's model. The demographic of the tourists and visitors are intentionally presented in the following sub-section to provide better understanding of the tourists' characteristics and to know which homestay proprietors attended to these tourists. This is also to determine whether the demographic characteristics do influence the 'modes of experiences' and 'QTE and motivation'.

\section{Demographic characteristics of tourists and visitors}

The total number of tourists interviewed for this research is 150 people. The background of the tourists are: 69 of the tourists' feedbacks are from Annah Rais Longhouse Adventure that belongs to Edward, 28 tourists' feedbacks are from the Macheree Homestay, 11 tourists' responses are from Bidayuh Annah Rais Longhouse Homestay belongs to Joda, there are 10 tourists participated in the research attended by Jenny Homestay and 20 tourists attended by Valerie Homestay. As for Esah and Emily homestays, 5 tourists respectively participated in the research. While another two more tourists did not indicate the homestay. The tourists' modes of visit are either day trip or overnight stay. Out of the total number of tourists, 122 tourists choose to stay overnight at Annah Rais village - these tourists stay at Annah Rais Longhouse Adventure, Bidayuh Annah Rais Longhouse, Jenny, Valerie, Esah and Emily homestays. Meanwhile 28 respondents visited the village for a day trip which was attended by Macheree homestay. Tourists who visited Kampung Annah Rais came from numerous countries. There are 84 Malaysian tourists who came from various states such as Sarawak, Selangor, Perak, Pahang, Kelantan, Kedah, Pulau Pinang, Terengganu and Negeri Sembilan. This followed by 11 tourists from Singapore and United Kingdom respectively, eight tourists from New Zealand, seven tourists from Australia, six tourists from Holland, five tourists from France, four tourists from Belgium, three tourists from Ireland and Hong Kong, Sweeden and Germany recorded two tourists arrival respectively. Indonesia and Switzerland recorded one tourist arrival respectively. Meanwhile two tourists did not indicate their country of origin. The 137 tourists stated that they visited Kampung Annah Rais for the first time while 12 tourists stated that they have visited the village more than once. However, one respondent did not state the number of visit to the village.

In relations to gender background, there are 57 male and 91 female tourists interviewed. Two of the respondents however did not indicate their feedback on the aspect. The age range set up for the respondents are ranging from 15 to 55 years old. The highest response was obtained from respondents between the ages of 21-25 years old with 63 respondents. Meanwhile the lowest response is from three respondents in between age range of 36 to 40 years old. The highest respondents interviewed are 82 students, 25 respondents who work in a private company, 21 pensioners, 12 respondents who work as government servant and 8 respondents are self-employed. Another two respondents did not indicate their feedback on the aspect. On the monthly income of respondents, 127 respondents did not provide any feedback on this aspect due to privacy matter. However, there are five respondents respectively saying that their income is in between RM 1,000 - 3,000; RM 7,000 - 9,000 and RM 10,000 13,000. Meanwhile there is one respondent respectively recorded an income in between RM 14,000 16,000 RM 17,000 - 19,000 and RM 20,000 - 23,000. Lastly, there are two respondents whose income is below RM 1,000. All the income was recorded according to respondents' currency and during the input data to SPSS software, the currency is then converted to Ringgit Malaysia. Respondents' interest is also recorded since it does influence the mode of experiences. There are 89 respondents indicate their hobby in relations to outdoor and adventurous activities, 23 respondents say that they like to travel and engage in leisure activities, 21 respondents say that their main hobby is 
photography, six respondents like to engage in arts and crafts activities, and five respondents say that their hobby is to learn about history. Another five more respondents did not state their hobby to any of the options provided and there is one missing value from the data.

\section{Bidayuh Annah Rais Longhouse (BARL) tourists' experiences on the performing arts}

In order to assess quality tourism experience, Killion's refurbished model of experiences is referred. The three phase of experiences; anticipatory, experiential and reflective are asses on the basis of tourists' feedback on their experiences of viewing the arts performances in particular the dance and music. Tourists' rating on their experiences of viewing and participating in the dance performance is; 91 tourists say they are anticipated in the dance performance while 21 tourists commented that they did not enjoy the dance performance and 38 tourists did not indicate their experiences. The 91 tourists who have anticipated in the dance performance also commented that they will definitely recommend BARL to their friends and relatives as well to re-visit the village if there is an opportunity. Comparatively, there are mixtures of both positive and undesirable comments uttered by the tourists. The 91 tourists' experiences can be categorized as both experiential and reflective since it emphasize on the element of return travel, recollection, planning and travel to. Meanwhile the 21 tourists' experiences does not confine to the three phases. Further follow-up in-depth interview was also conducted with two different groups of tourists. There are two different feedbacks gathered to understand in detail the pattern of data collected. First group is three Malaysian tourists who commented that they did not anticipate in the dance performance because the dance choreography is less entertaining as compared to the cultural performance in Sarawak Cultural Village (SCV). Their feedbacks are then crosstab with some of the demographic characteristics such as mode of visit, frequency of visit, homestay proprietors that attended this group and tourist' interest. The three tourists are attended by Jenny homestay who visited the village on day trip for the second time. All of them express an interest in outdoor and adventure activity. Meanwhile the second group is Australian tourists who commented that they enjoy the dance performance because it retains the aesthetic value within the natural setting. Their feedback is also crosstab with similar demographic characteristics as the Malaysian tourist; these four Australian tourists are attended by Edward homestay who stay overnight in the village. Three of the tourists express their interest in outdoor and adventure activity while one tourist respectively says that they like doing photography and learn about history of others. The conclusion that can be drawn from this pattern is that there is no clear indicator to relate the demographic characteristics to tourists' feedback on their experiences of viewing the performing arts. However, it is worth to emphasize that Edward homestay often received overwhelming feedback from tourists not just because of the structure of the homestay programme but also due to the hospitality and services rendered by the homestay proprietor that possess more experiences in the business.

As for the tourists' feedback on their experiences of viewing and participating in the music performance, 91 tourists indicate that there are anticipated in the music performance. However, 21 tourists commented that the music performance is unpleasant - 'very poor' remark is given by three Malaysian and Holland tourists respectively, two France tourists, one tourist respectively from Ireland, Germany and Sweden. While 9 tourists' commented the music performance is 'poor' - six Malaysian tourists, two from England and one tourist respectively from Singapore and Sweden. Meanwhile the remaining 38 tourists did not provide their feedback. In the follow up in-depth interview with a group of 27 anticipated students, who visited the village on day trip basis and was attended by Macheree homestay, the on-site experience in relations to the music performance is determined by tourists' 'active' and 'passive' participation in the cultural performances. All the 27 students stated that the opportunity to personally learned the bamboo musical instruments provide solid foundation in recommending BARL tourism to their friends and relatives. Hence, in the context of BARL tourism, the music performance does encourage the anticipatory and on-site experience which eventually influences the reflective phase.

Back to the main focus of this research on the lesson learn from BARL tourism experiences in relation to preserving performing arts, it can be concluded that both homestay proprietors and tourist 
experiences are the major determinant in the preservation effort. Hence, the homestay programme should benefits both parties. The constructive feedback and views uttered by tourists in relations to their experiences of visiting the place should be included in the organization and planning of the homestay programme. This is for a reason that tourist's reflective experiences is significant to sustain the programme through the process of re-collection, re-visit and recommendation.

\section{CONCLUSIONS}

Community based tourism and homestay proprietors play crucial roles in perpetuating and ensuring the survival of Bidayuh performing arts. The roles of homestay proprietors are measured based on their conformity in showcase the performing arts. Meanwhile, tourist experiences are measured in line with Killion's travel model experience inclusive of both constructive and unpleasant experiences. In cultural heritage management both experiences are important to be examined and relooked to sustain the CBT development. Apart from that, it is also to sustain the holistic socioeconomic benefits gain by the rural community. Hence, this study implies that the management and planning of CBT development in any rural village should implicitly incorporated all the three-prone agendas of CBT. Various tourism networks of any levels also should be considered as important aspect in the management and planning of CBT development.

\section{ACKNOWLEDGEMENT}

This research was supported by Research Acculturation Grant Scheme RAGS/SS/09(1)/912/2012(13) from Ministry of Higher Education, Malaysia.

\section{REFERENCES}

Ashley, C., Boyd, C., \& Goodwin, H. (2000). Pro-poor tourism: Putting poverty at the heart of the tourism agenda. London: Overseas Development Institute.

Chang, P. F. (2002). History of Bidayuh in Kuching Division, Sarawak. Sarawak Press.

Dias, T. (2001). Tourism and Longhouse Communities, Working Paper Series (6), Institute of East Asian Studies, University of Malaysia Sarawak (UNIMAS), Kota Samarahan, Sarawak.

Goodwin, H. (2007). Indigenous tourism and poverty reduction in Butler, R. \& Hinch, T. (eds.), Tourism and Indigenous Peoples, Butterworth-Heinemann.

Harrison, D., \& Schipani, S. (2007). Lao Tourism and Poverty Alleviation: Community-Based Tourism and the Private Sector. Current Issues in Tourism, 10(2), 194-230.

Hon, D. (1989). Culture designed for tourism: The Sarawak Context, Sarawak Museum Journal, 40(1): 285-292.

Hughes, H. L. (2000). Arts, entertainment and tourism. Oxford: Butterworth-Heinemann.

Jennings, G., \& Nickerson, N. P. (2006). Quality tourism experiences. Amsterdam: Elsevier Butterworth-Heinemann.

Kedit, P.M. (1980). Tourism Report: Skrang River. A Survey on the Effects of Tourism on Iban Longhouse Communities in the Skrang District. Second Division. Sarawak, Sarawak Museum Field Report, No. 2. Kuching Sarawak. 
Kedit, P.M., \& Sabang, C.L. (1993). Tourism report: A re-study of Skrang longhouse tourism, in Victor T.K. (ed.), Tourism in Borneo, Borneo Research Council Proceedings, 4: 45-58.

Mohd Nor, Nor Ashikin., \& Kayat, Kalsom. (2010). Conference paper The Challenges of Community-Based Homestay Programme in Malaysia in Proceedings of Regional Conference on Tourism Research, Universiti Sains Malaysia, Penang, Malaysia.

Othman, Fadina., Sazali, Ferdhaus., \& Mohamed, Badaruddin. (2013), Rural and Community Based Tourism Development in Malaysia: Prospects for Homestays as a Social Economic Enterprise in Journal of Hospitality and Tourism, 10(1): 65-76.

Pusiran, A. K., \& Xiao, H. (2013). Challenges and Community Development: A Case Study of Homestay in Malaysia. Asian Social Science, 9(5).

Razzaq Abdul, Rasid Abdul., \& Ibrahim, Yahaya. (2011). Homestay Program and Rural Community Development in Malaysia.

Rusell, P. (2000). Community-based tourism. Travel \& Tourism Analyst 5: 87-114.

Samat, T. P. (2011), Ethnic Tourism and the Bidayuh indigenous people of Sarawak. A case study of Annah Rais village, M.A thesis, Latrobe University Australia.

Sanggin, S. E. (2009). Community Involvement in Culture and Nature Tourism in Sarawak, Akademika, 77:149-165.

Sita, S. E., Nor, N. A., \& Sita, S. E. (2015). Local Perceptions towards Tourism Impacts Related to Homestay Programme. Journal of Management Research, 7(2), 274-285.

Vinh, N.Q. (2013). Destination Culture and Its Influence on Tourist Motivation and Tourist Satisfaction of Homestay Visit, Journal of the Faculty of Economics and Administrative Sciences, Cankiri Karatekin Universitesi Iktisadi ve Idari Bilimler Fakultesi Dergisi, 3(2): 199-222.

Williams, R. (1981). Towards Sociology of Culture in Culture. London: Fontana Press.

Zeppel, H. (1995). Authenticity and Iban Longhouse Tourism in Sarawak, Borneo Review, 6(2): 109125.

(1997). Meeting Wild People: Iban Culture and Longhouse Tourism in Sarawak, in Shinji Yamashita, Kadir H. Din \& J.S Eades (eds.), Tourism and Cultural Development in Asia and Oceania, Universiti Kebangsaan Malaysia Bangi, Malaysia.

(n.a.). Sarawak Homestay Directory (n.d), Kementerian Pelancongan Malaysia. 